\title{
REVERSES OF ANDO AND DAVIS-CHOI INEQUALITY
}

\author{
R. MIKIĆ, J. PEČARIĆ AND I. PERIĆ
}

\begin{abstract}
Reverse Ando's inequalities for positive linear maps are deduced. A difference reverse inequality is proven for solidarities one of which is of a special type that includes connections. A quotient reverse inequality (or an operator reverse Hölder inequality) for connections and for the special type of solidarities that includes connections is given. As an application an operator reverse of Hölder's inequality for the general weighted power mean is given in a difference and a quotient form. An analogous inequality in a difference form for the relative operator entropy is directly proven. An another type of reverse inequalities is given for Ando's and Davis-Choi's inequality. The estimations in this case are expressed using a kind of variation of involved family of operators.
\end{abstract}

Mathematics subject classification (2010): 47A63, 47A64.

Keywords and phrases: Kubo-Ando means, connections, solidarities, Lah-Ribarič inequality, reverse inequalities.

\section{REFERENCES}

[1] W. N. Anderson JR., R. J. Duffin, Series and parallel addition of matrices, J. Math. Anal. Appl. 26 (1969), 576-594.

[2] T. ANDO, Concavity of certain maps on positive definite matrices and applications to Hadamard products, Linear Algebra Appl. 26 (1979), 203-241.

[3] J. S. AuJla, H. L. VASUdeVA, Inequalities involving Hadamard product and operator means, Math. Japon. 42 (1995), 265-272.

[4] J.-C. Bourin, E.-Y. LeE, M. FujII, Y. SEO, A matrix Hölder inequality, Linear Algebra Appl. 431 (2009), 2154-2159.

[5] M. D. CHOI, A Schwarz inequality for positive linear maps on C*-algebras, Ill. J. Math. 18 (1974), 565-574.

[6] C. Davis, A Schwarz inequality for convex operator functions, Proc. Amer. Math. Soc. 8 (1957), $42-44$.

[7] S. S. DRAGOMIR, Some reverses of the Jensen inequality with applications, RGMIA Res. Rep. Coll. 14 (2011), Art. 1, 1-10.

[8] J. I. FujiI, M. FujiI, Yuki Seo, An extension of the Kubo-Ando theory: Solidarities, Math. Japonica 35, 2 (1990), 387-396.

[9] J. I. FUJII AND E. KAMEI, Relative operator entropy in noncommutative information theory, Math. Japon. 34 (1989), 341-348.

[10] M. FUJII, E.-Y. LEE, Y. SEO, A difference counterpart to a matrix Hölder inequality, Linear Algebra Appl. 432 (2010), 2565-2571.

[11] M. FujiI, J. MićIć Hot, J. PeČArić, Y. Seo, Recent Developments of Mond-Pečarić Method in Operator Inequalities, Monographs in Inequalities 4, Element, Zagreb, 2012.

[12] S. Furuichi, K. YANAGI, K. KURIYAma, Fundamental properties of Tsallis relative entropy, J. Math. Phys. 45 (2004), 4868-4877.

[13] S. FURUICHI, K. YANAGI, K. KURIYAMA, A note on operator inequalities of Tsallis relative operator entropy, Linear Algebra Appl. 407 (2005), 19-31.

[14] T. FURUTA, Two reverse inequalities associated with Tsallis relative operator entropy via generalized Kantorovich constant and their applications, Linear Algebra Appl. 412 (2006), 526-537. 
[15] T. Furuta, J. Mićić Hot, J. Pečarić, Y. Seo, Mond-Pečarić Method in Operator Inequalities, Monographs in Inequalities 1, Element, Zagreb, 2005.

[16] R. JAKŠIĆ, M. KRNIĆ, J. PEČARIĆ, A more accurate converses of the Jensen and Lah-Ribarič operator inequality, submitted for publication.

[17] R. KaUR, M. Singh, J. S. Aujla, Generalized matrix version of reverse Hölder inequality, Linear Algebra Appl. 434 (2011), 636-640.

[18] F. Kubo, T. Ando, Means of positive linear operators, Math. Ann. 246 (1980), 205-224.

[19] E.-Y. LEE, A matrix reverse Cauchy-Schwarz inequality, Linear Algebra Appl. 430 (2009), 805-810.

[20] J. MiĆIĆ, J. PEČARIĆ, Y. SEO, Complementary inequalities to inequalities of Jensen and Ando based on the Mond-Pečarić method, Linear Algebra Appl. 318 (2000), 87-107.

[21] J. E. PeČArić, F. Proschan, Y. L. TONG, Convex functions, partial orderings and statistical applications, Academic Press Inc., 1992.

[22] Y. SEO, Reverses of Ando's inequality for positive linear maps, Math. Inequal. Appl. 14 (2011), 905910. 